\title{
Design of helical-blade rotor of Vertical Axis Wind Turbine (VAWT)
}

\author{
Buyung Junaidin* \\ Departemen Teknik Dirgantara, Sekolah Tinggi Teknologi Adisutjipto \\ Email : buyung112011@gmail.com
}

\begin{abstract}
The vertical axis wind turbine (VAWT) with helical-blade has been developed, manufactured and applied in almost all developed countries. In Indonesia, vertical axis wind turbines are still not widely applied compared to horizontal axis wind turbines. Vertical axis wind turbines with helical-blade are still very rare in Indonesia. Research and development of the vertical axis wind turbine are needed because of its advantages compared to horizontal axis wind turbine. The advantages are: can operate in various wind directions, lower noise due to smaller tip speed ratio (TSR) and for large-scale, mechanical and electrical systems of turbine can be placed on ground. The aim of this research is to design a vertical axis wind turbine rotor with helical-blade that can be applied at low speeds and changing direction wind condition, such as urban wind characteristics. Performance analysis of wind turbine rotor is done by using the double-multiple stream-tube (DMS) model approach. This research yields a rotor of vertical axis wind turbine with helical-blade with rotor length and diameter are $2 m$ and $1 m$ respectively, the rotor blade airfoil is DU-06-W-200 with chord length is $0.2 \mathrm{~m}$. From analysis, the optimum tip speed ratio of the rotor is 2.6 with a maximum power coefficient is 0.57 .
\end{abstract}

Keywords: Design, Helical-Blade, Vertical Axis Wind Turbine.

\section{Pendahuluan}

Teknologi turbin angin poros vertikal atau vertical axis wind tubine (VAWT) menawarkan banyak kelebihan dibanding turbin angin poros horizontal, antara lain tidak berpengaruh pada arah angin (dapat beroperasi pada berbagai arah angin), kebisingan lebih rendah karena tip speed rasio (TSR) lebih kecil dan untuk skala besar penempatan sistem mekanis dan elektriknya dapat ditempatkan di dasar ( round). VAWT dirancang berdasarkan kriteria desain dan pertimbangan performa yang diinginkan seperti desain Darrieus dengan bentuk rotor- $\mathrm{H}$, bentuk rotor- $\mathrm{V}$ dan bentuk rotor-Troposkein. Turbin angin tipe Darrieus memanfaatkan gaya aerodinamika untuk berputar. Terdapat periode dalam pemanfaatan angin oleh setiap bilah selama turbin berputar, hal ini menjadi kekurangan bagi turbin itu sendiri karena pada satu periode tidak semua bilah menghasilkan gaya aerodinamika yang dapat memutar turbin. Kekurangan ini disempurnakan oleh A. Gorlov dengan mengembangkan turbin angin dengan bentuk bilah puntir berbasis bentuk rotor-H dari tipe Darrieus, yang kemudian dipatenkan pada pertengahan tahun 1990 untuk aplikasi hidrodinamika dan baru diadaptasi untuk aplikasi turbin angin sejak awal tahun 2000.

Turbin angin poros vertikal dengan bentuk rotor-helix telah banyak dikembangkan, dibuat dan diaplikasikan di hampir semua negara maju. Di Indonesia sendiri, turbin angin poros vertikal masih belum 
banyak diaplikasikan jika dibandingkan turbin angin poros horizontal. Turbin angin poros vertikal dengan bentuk bilah puntir masih sangat jarang ditemui. Penelitian dan pengembangan dari turbin angin poros vertikal diperlukan karena kelebihannya dibandingkan turbin angin poros horizontal, yang hasilnya diharapkan mampu mendukung kebijakan pemerintah dalam pemanfaatan energi terbarukan khususnya energi angin.

Penelitian ini berpusat pada perancangan rotor turbin angin poros vertikal dengan bentuk bilah puntir yang dapat diaplikasikan pada kecepatan angin rendah dan berubah-ubah arah seperti karakteristik angin di perkotaan. Analisis performa rotor tubin angin dilakukan dengan pendekatan model double-multiple stream-tube (DMS).

\section{Metodologi Penelitian}

Model double-multiple stream-tube atau biasa dikenal dengan model DMS adalah salah satu dari sekian banyak pendekatan yang bisa digunakan memodelkan performa dari suatu VAWT [1]. Model DMS termasuk dalam momentum model yang berdasarkan prinsip konservasi momentum yang diturunkan dari persamaan hukum Newton kedua. Model ini telah sukses untuk memprediksi torsi dan beban thrust dari rotor tipe Darrieus. Model DMS dikembangkan oleh I. Paraschivoiu untuk menghitung beban aerodinamika bilah dan performa rotor pada VAWT tipe Darrieus dengan konfigurasi straight blade dan curve blade [2]. Model MDS mengaplikasikan teori piringan aktuator pada upstream dan downstream dari rotor. Teori ini menganggap turbin angin sebagai sebuah piringan yang menciptakan perubahan diskontinuitas tekanan dari aliran udara yang melewati stream-tube. Perubahan tekanan ini mengakibatkan perlambatan kecepatan udara yang menghasilkan kecepatan induce. Ilustrasi penggunaan model DMS untuk analisis VAWT seperti pada Gambar 1.
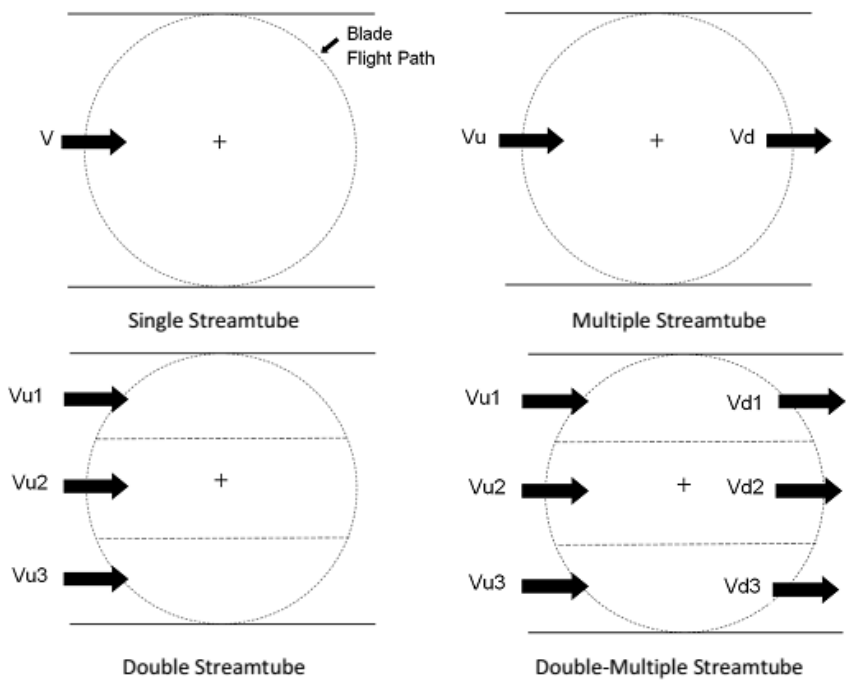

Gambar 1. Model stream-tube untuk analisis VAWT

\section{Hasil dan Pembahasan}

\subsection{Perancangan Rotor VAWT}

\section{i. Batasan Perancangan}

Proses perancangan turbin angin dimulai dengan menentukan konsep turbin angin. Penentuan konsep turbin angin mempertimbangkan batasan-batasan dan pertimbangan yang menjadi acuan dalam proses perancangan. Batasan-batasan dan pertimbangan ini diperoleh berdasarkan kajian dari penelitian sebelumnya, antara lain:

1. Turbin angin vertikal dirancang untuk kondisi urban dengan bentuk bilah puntir. Kecepatan angin $(v)$ minimum $2,5 \mathrm{~m} / \mathrm{s}$. 
2. Aspek rasio $(A R=H / D)$ rotor sebesar 2 untuk bilangan Reynold kecil [3].

3. Tinggi $(H)$ dan diameter $(D)$ rotor masing-masing adalah $2 \mathrm{~m}$ dan $1 \mathrm{~m}$.

4. Jumlah bilah rotor yang digunakan adalah 3 bilah dengan sudut puntir 45deg untuk memaksimalkan pemanfaatan angin [4].

5. Pemilihan airfoil mempertimbangkan beberapa hal:

- Bentuk airfoil simetri atau semi simetri

- Sedikit chamber (hingga 4\%) untuk tujuan self-starting.

- Ketebalan airfoil antara $12-20 \%$ dari panjang chord.

6. Panjang chord bilah yang digunakan adalah $0,2 \mathrm{~m}$.

7. Perkiraan awal nilai tip speed rasio (TSR) adalah 2.

ii. Data Angin

Proses perancangan rotor turbin angin memerlukan data angin berupa kecepatan, kerapatan dan viskositas yang akan digunakan dalam perhitungan. Data-data yang akan digunakan adalah:

- Kerapatan udara $(\rho)=1,212 \mathrm{~kg} / \mathrm{m}^{3}$

- Kecepatan angin minimum $(v)=2,5 \mathrm{~m} / \mathrm{s}$

- Viskositas $=1,8 \times 10^{-5} \mathrm{~N} / \mathrm{m}^{2} \mathrm{~s}$

iii. Perkiraan Awal Performa Rotor Turbin Angin

Luas swept area $(S)$ pada turbin angin dihitung dengan persamaan:

$$
S=H D
$$

Hasil perhitungan diperoleh nilai $S=2 \mathrm{~m}^{2}$.

Power yang dihasilkan dari angin dihitung dengan persamaan:

$$
P_{A}=1 / 2\left(\rho S v^{3}\right)
$$

Nilai power angin diperoleh $P_{A}=19 \mathrm{~W}$.

Batas Bezt menyatakan bahwa rata-rata turbin angin hanya memanfaatkan 16/25 dari energi kinetik angin $\left(P_{A}\right)$. Power yang dihasilkan turbin dihitung dengan persamaan:

$$
P_{T}=16 / 251 / 2\left(\rho S v^{3}\right)
$$
$2,5 \mathrm{~m} / \mathrm{s}$.

Dari persamaan 3 diperoleh nilai power yang dihasilkan rotor turbin $12 \mathrm{~W}$ pada kecepatan angin

iv. Analsis Rotor Turbin Angin

Analisis performa rotor turbin angin dilakukan dengan software QBlade yang berbasis metode DoubleMultiple Stream-tube (DMS). Dalam proses analisis, langkah pertama yang dilakukan adalah memodelkan rotor turbin angin. Pemodelan rotor membutuhkan data geometri termasuk di dalamnya jenis airfoil yang digunakan. Pemilihan airfoil mempertimbangkan kriteria yang telah ditentukan sebelumnya. Airfoil yang digunakan adalah DU-06-W-200 [5]. Bentuk airfoil yang digunakan dan hasil pemodelan rotor turbin angin sesuai gambar 2 dan gambar 3.

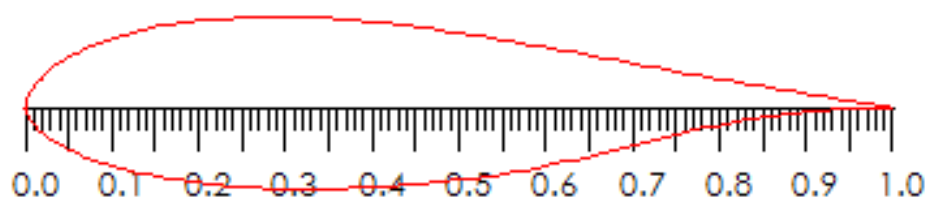

Gambar 2. Bentuk Airfoil DU-06-W-200 


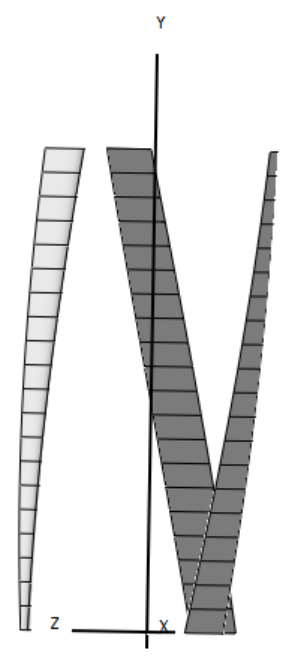

Gambar 3. Model Rotor Turbin Angin

Dari model yang telah dibuat (gambar 3.2) dilakukan analisis dengan kondisi lingkungan yang sama seperti perhitungan perkiraan performa awal dan variasi parameter nilai TSR untuk mendapatkan nilai TSR optimum (koefisien power maksimum). Dari hasil analisis diperoleh nilai TSR optimal rotor sebesar 2,6 dengan koefisien power rotor maksimum sebesar 0,57 sesuai grafik pada gambar 4 .

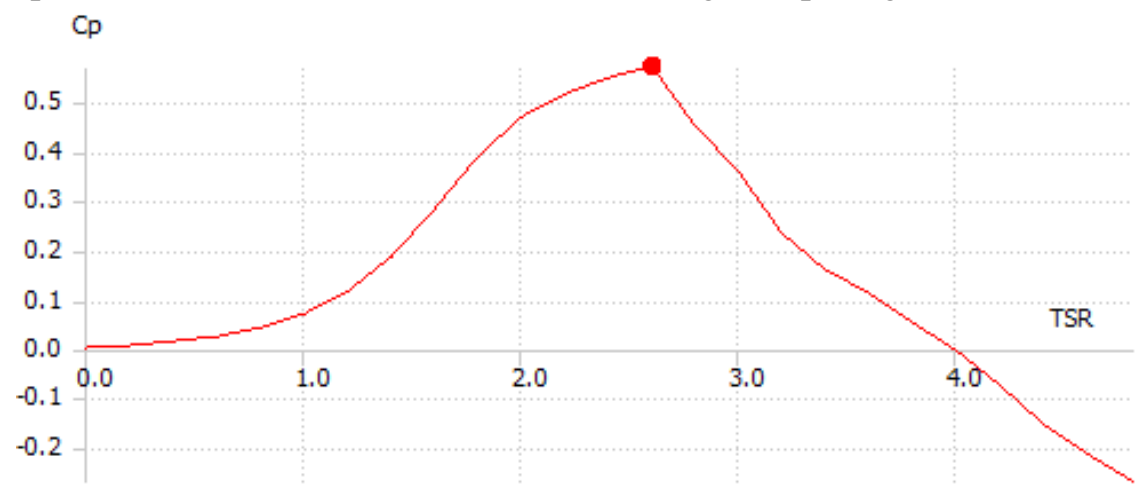

Gambar 4. Hubungan Koefisien Power dan TSR Turbin Angin

Dari hasil analisis dengan metode DMS diperoleh koefisien power maksimum rotor turbin sebesar 0,57 sehingga menghasilkan power turbin sebesar 10,8W. Hasilnya ini lebih kecil $12 \%$ dari perkiran awal sebesar $12 \mathrm{~W}$.

\section{Kesimpulan}

Dari hasil perancangan diperoleh geometri vertical axis wind turbine (VAWT) skala kecil dengan spesifikasiterlihat pada Tabel 1 .

Tabel1. Geometri Vertical Axis Wind Turbine (VAWT) skala kecil

\begin{tabular}{ll}
\hline \multicolumn{1}{c}{ Parameter } & Ukuran \\
\hline Diameter rotor & $1 \mathrm{~m}$ \\
Tinggi rotor & $2 \mathrm{~m}$ \\
Jumlah bilah & 3 \\
Panjang chord bilah & $0,2 \mathrm{~m}$ \\
Jenis airfoil & DU-06-W-200 \\
Sudut serang awal & $0 \mathrm{deg}$ \\
Kecepatan minimum & $2,5 \mathrm{~m} / \mathrm{s}$ \\
\hline
\end{tabular}


Hasil analisis rotor turbin dengan metode DMS diperoleh nilai TSR optimal rotor turbin sebesar 2,6 yang menghasilkan koefisien power maksimum sebesar 0,57.

\section{Daftar Pustaka}

[1] Cooper, P. (2010). Development and analysis of vertical-axis wind turbines. Wind Power Generation and Wind Turbine Design, 277.

[2] Paraschivoiu, I. (2002). Wind turbine design: with emphasis on Darrieus concept. Presses inter Polytechnique.

[3] Brusca, S., Lanzafame, R., \& Messina, M. (2014). Design of a vertical-axis wind turbine: how the aspect ratio affects the turbine's performance. International Journal of Energy and Environmental Engineering, 5(4), 333-340.

[4] Junaidin, B. (2018). MODIFICATION OF ROTOR BLADES SHAPE OF VERTICAL AXIS WIND TUBINE (VAWT). Angkasa: Jurnal Ilmiah Bidang Teknologi, 10(2), 141-148.

[5] Jayabalan, Krishnaraj \& ellappan, sivakumar \& Kumar, Anil. (2019). Additive Manufacturing of a Gorlov Helical Type Vertical Axis Wind Turbine. International Journal of Engineering and Advanced Technology. 9. 2639-2644. 10.35940/ijeat.B4116.129219. 
